\title{
Organizational Conflict Causes: An Application Example in Health Sector
}

\author{
Sedat Bostan*, Fatma Çiftçi, Taşkın Kiliç \\ Department of Health Care Management, Gumushane University, Turkey
}

Copyright $(2016$ by authors, all rights reserved. Authors agree that this article remains permanently open access under the terms of the Creative Commons Attribution License 4.0 International License

\begin{abstract}
Object: The object of this study is to detect possible conflict causes in the healthcare organizations, to determine how the organization employees are affected, and to allow the applicable solutions in these conflicts to be predicted. Material-Method: Study samples were obtained from 150 personnel of Kara Mustafa Paşa Public Hospital in Merzifon, Amasya. Data were collected via "A Scale for Conflict Causes" and analyzed. Findings and Result: According to the study results it was determined that major cause of conflict in the healthcare organization forming our samples was due to uncertainty of authorization and responsibility in the organization, and imbalance between authorization and responsibility.
\end{abstract}

Keywords Conflict, Conflict Management, Organizational Conflict Causes

\section{Introduction}

Human being which is a social being spends most of his lifetime in various organizations. Humans have a social relationship and communication network in the organizations established to perform certain goals. Undoubtedly, in this environment humans will affect the organization with which they are in a relationship and also they will be affected by the organization structure in accordance with the organization culture. Today's organizations have become complicated in parallel with rapidly emerging communication network and globalization and accordingly, their differences between individuals and organizations have increased. As a result, disagreements and conflicts between the employees having different working habits and labor discipline under the influence of individual values, differences in belief and perception, education and area of residence have become unavoidable. It is so natural that the people disagree or conflict with each other in an organization, as much as they get on well and work in harmony with each other. It is inevitable that conflicts arise as a result of the disagreements between them, no matter how they are well-intentioned, as long as the people live together. (Akca and Erigüç,2006:127)

Conflict concept is defined a variety of reasons resulting from the dispute between two or more individuals or groups (Koçel, 2003: 664); disagreement or incompatibility caused by scarce source sharing or activity distribution between two or more individuals or groups, and by status, goal, value or perception differences between the same individuals or groups within the organization (Şimşek, 2002:288); chain of events which are caused by co-working problems of individuals and groups and which stop normal activities or lead to new problems (Eren, 2009: 585); and two or more individuals or organization units performing the same activity within the organization whose expectations have not been realized or who haven't taken advantage of a potential benefit (Öztürk, 1992: 35). In the literature, conflict concept has various definitions which reflect similar or different aspects. As a phenomenon and behavior for being opposite which occurs in the case of an interaction process occurring as a disagreement, discrepancy or incompatibility between the social beings such as an individual, a group, an organization, etc. (Rahim, 1983; 1); Key elements of a conflict are disagreement, opposition, adverseness, nonoccurrence and opposition, regardless of how it is defined (Aşçıŏlu, 2007:3).

In our contemporary world, organizations encounter conflict potential frequently due to intensifying competition, impacts of globalization and cultural differences in work force; and thus, managements are required to spend more time and energy on this issue than ever (Sigri and Dincer: 2013:195). In the initial definitions of conflict concept, only human factor was included. Conflict is defined as a natural issue since human beings might oppose to themselves and/or with each other due to their genetic differences (Sutton, 1976:1093). Afterwards, organizations and organization members have been included in the definition beside the human factor considered as the single factor of conflict. Thus, conflict was defined as differentiation of interests, aims or priorities among individuals, groups or organizations, or inconformity among tasks, activities or processes (Gardiner and Simmons, 2003:109). 
Since conflict does not exist only among human beings, it is classified under five groups in terms of parties included in process; Internal conflicts of individuals, Inter-personal conflicts, Conflicts between individuals and groups, Conflicts within and between groups, Inter-organizational conflicts (Kocel, 2007:648).

Opinions regarding organizational conflicts are classified under three titles: Conventional Approach: Conventionalist organizational theoreticians viewed conflict in destructive characteristic; and they have defended that organizations are required to be cleared off from conflicts so that organizations could maintain their functions properly (Akatay, 2003:58).

Human Affairs Approach: According to this view, conflicts among human affairs and groups are inevitable and natural. According to human affairs approach, conflicts which arise on the basis of differences among individuals or within group are not totally destructive for organization; they might have some positive consequences as well to some extent (Akatay, 2003:58).

Interactionist Approach: Pursuant to the modern management understanding, conflicts are inevitable for organizations and desirable for certain circumstances (Akkirman, 1998:7). Conflicts which occur in organizations because of reasons different than behavioral causes were supported and they were set forth through an innovative understanding (Demireli and Munzur, 2015:296). In organizations in which persistent and important conflicts experienced, necessary decisions will be delayed, failed and compromises will then be not enough to resolve problems in the organization; on the other hand, in the organizations in which no any conflict arise, organizational performance will be adversely affected and its survival will be jeopardized because of lack of adequate innovation, change and creativity (Kocel, 1993:645).

This is one of the most frequent models of our contemporary time and it categorizes conflict management strategies in two separate dimensions. Rahim et al. (2002:305) categorize conflict and conflict management styles under groups by correlating individual self-interest consideration and individual emphatically interest consideration dimensions. Five dealing ways acquired by correlation of these two dimensions were exhibited below:

\begin{tabular}{|c|c|c|c|c|}
\hline \multicolumn{2}{|c|}{} & \multicolumn{3}{|c|}{ Self-oriented interest } \\
\cline { 3 - 3 } & High & & Low \\
\hline \multirow{2}{*}{$\begin{array}{c}\text { Interest } \\
\text { oriented } \\
\text { to others }\end{array}$} & High & $\begin{array}{c}\text { Integration } \\
\text { (High/Low) }\end{array}$ & $\begin{array}{c}\text { Reconciliation } \\
\text { (Partially }\end{array}$ & $\begin{array}{c}\text { Conforming } \\
\text { (Low /High) }\end{array}$ \\
\cline { 2 - 3 } & $\begin{array}{c}\text { Domination } \\
\text { (High/Low) }\end{array}$ & High/Low) & $\begin{array}{c}\text { Avoiding } \\
\text { (Low/Low) }\end{array}$ \\
\hline
\end{tabular}

Figure 1. Conflict Management Strategy Model (Rahim et al. 2002)

Integration is practiced in strategy which prioritizing interest of counter party as much as self-interest to resolve current problems for both parties. Conforming is the strategy which requires giving compromise by prioritizing interest of counter party with respect to self-interests. Domination is the strategy which prioritize self-interests while minimizing interests of counter party and dominating others. Avoiding is the strategy suggesting avoidance, aversion and prevention since both self-interest and interest of counter party are low. Reconciliation is the strategy which prescribes showing minor compromises from both parties since emergency of fulfillment of needs of both parties are at medium levels. Finding a common enemy is the strategy employed in conflict management in cases which depend on strategies such as making decision based on the view of the dominant party; increasing communication, team management, compromising, replacement of employees, changing organizational relationships, punishment, cooperation and determining target (Kilinc, 1986:35; Akkirman, 1998:7; Ada, 2013:65).

Conflicts and disagreements are encountered when individuals have valuable and indispensible targets. If inter-personal conflicts are not managed constructive way, anger, hostility and even violence could arise within the organization; and thus, they could end up with pain, sorrow and separation (Turnuklu et al., 2009:5). However, if an organization succeeds in management of a conflict case constructively when it arises, it could maintain its operations at desired levels. Development of new procedures and management styles for market and work force, advancements in technology and intensifying competition require new products and services to answer changes in customer perceptions; consequently this new status necessitates conflict management (Tjosvold, 1991:16). In the meantime: Allows formation of new, unique and creative ideas; Incents productivity and innovation and increases tendency to make more research (introduces creativity and novelty); Motivates for change, considers new opinions and ideas; Breathes new life into the organization; Enables individuals and groups to gain personality characteristics; Increases organizational commitment and enhances performance; Allows employees to explore their knowledge, skill and characteristics and to assess themselves; Provides opportunity to express issues safely and clearly (Sims, 2002:246; Ohbuchi and Suzuki, 2003:71-72; Meric, 2012:25-27)

Because demands for health sector increase day by day, analysis of factors effecting productive and efficient use of the hospitals has become important. The most important factor is the organizational conflict. In order to manage the conflicts such that they serve for the hospital goals the managers primarily should know the conflict causes encountered in the organizations (Aktaş, 2002). Hospital organization in terms of organizational conflict, the dispute between the staff involved in the patient care process, incompatibility, part complexity, especially in the job uncertainty can be considered as a comprehensive concept that includes the various conflicts elements (Ocak, 2004: 54-62). The main causes of conflict experienced in hospital can be listed as follows (Ergün 1999; Kashanian, 1991; Doğrusöz 1987, Aslan 2004; Koçel 2003): Communication Failure mutual task dependencies, status differences, Duties authorities of and the uncertainty of responsibility, detecting 
differences, objective interests and values differences, matrix structures, to participate in decisions, control style, member of differences, differences of reward system can be listed as a major shortage of resources.

The object of this study is to determine causes of conflicts occurring between the employees in the hospitals and to detect differences of these causes according to occupational and demographical variables. It is expected that the findings that will be obtained as a result of the study contribute to understanding the causes of the conflicts and provide information on conflict management for the hospital managers.

\section{Material and Method}

This study was performed at Kara Mustafa Paşa Public Hospital in Merzifon, Amasya between 8 and 15 April 2015. Samples for this study consisted of 150 personnel working in the hospital. Simple (random) sampling method was used in the study. Organizational Conflict Scale which is based on five-point Likert Scale and has been developed by Rahim and Bonoma was used as a data collection means in the study. Reliability of the scale was detected via Cronbach's Alpha value of 0.846 . Validity of the scale was tested by confirmatory factor analysis.

\begin{tabular}{|c|c|c|}
\hline \multicolumn{2}{|c|}{$\begin{array}{c}\text { Kaiser-Meyer-Olkin Measure of Sampling } \\
\text { Adequacy }\end{array}$} &, 842 \\
\hline \multirow{4}{*}{ Bartlett's Test } & $\begin{array}{c}\text { Approximately } \\
\text { Chi-Square }\end{array}$ & 2524,623 \\
\cline { 2 - 3 } & Df & 561 \\
\cline { 2 - 3 } & Sig &, 000 \\
\hline
\end{tabular}

KMO value of the scale was determined as $0,842(p=0,000)$ and it was decided that this was suitable for factor analysis.

\section{Findings}

Findings of the study are provided below.

Table 1. Title, Education Level, Study Year, Year of the Occupation and Gender Studies Percentage Breakdown of Features

\begin{tabular}{|c|c|c|c|}
\hline Variables & Categories & Number (n) & $\%$ \\
\hline \multirow{6}{*}{ Position } & Administrative Staff & 38 & 25,3 \\
\hline & Health Technician & 30 & 20,0 \\
\hline & Support Staff & 26 & 17,3 \\
\hline & Nurse & 48 & 32,0 \\
\hline & Doctor & 8 & 5,3 \\
\hline & Total & 150 & 100,0 \\
\hline \multirow{5}{*}{ Education Level } & Primary School & 5 & 3,3 \\
\hline & High School or Equivalent & 54 & 36,0 \\
\hline & Graduate & 82 & 54,7 \\
\hline & Postgraduate / Doctorate & 9 & 6,0 \\
\hline & Total & 150 & 100,0 \\
\hline \multirow{3}{*}{ Gender } & Female & 98 & 65,3 \\
\hline & Male & 52 & 34,7 \\
\hline & Total & 150 & 100,0 \\
\hline \multirow{5}{*}{ Year of Working } & Less than 1 year & 59 & 39,3 \\
\hline & 1-5 Years & 61 & 40,7 \\
\hline & $6-10$ Years & 26 & 17,3 \\
\hline & $11-15$ Years & 4 & 2,7 \\
\hline & 16 Year and Over & 150 & 100,0 \\
\hline \multirow{6}{*}{ Working in Occupation Year } & Total & 7 & 4,7 \\
\hline & Less than 1 year & 45 & 30,0 \\
\hline & 1-5 Years & 34 & 22,7 \\
\hline & 6-10 Years & 20 & 13,3 \\
\hline & 11-15 Years & 44 & 29,3 \\
\hline & Total & 150 & 100,0 \\
\hline
\end{tabular}


When distribution of the employees participated in the study by their job titles was evaluated it was clear that the occupational group in which maximum participation was seen included nurses with a ratio of $32,0 \%$ whereas the occupational group in which minimum participation was seen included doctors with a ratio of $5,3 \%$, as seen in Table 1 . When education level was evaluated it was seen that maximum participation was for individuals who were university graduate with a ratio of $54,7 \%$ whereas minimum participation was for individuals who were primary school graduate with a ratio of $3,3 \% .65,3 \%$ of participants were females and $34,7 \%$ of them were males. When working years of the participants were evaluated, it was seen that $30,0 \%$ of the participants were worked for 1-5 years, 29,3 of them were worked for 16 years and more, and $4,7 \%$ of them were worked for less than one year.

As a results of the analysis of the conflict causes listed in Table 2, the highest valued expressions calculated according to the employees' answers to measures regarding the conflict causes are indicated as follows: a score of 3.58 indicates imbalance between authorization and responsibility; an average score of 3.66 indicates uncertainty between authorization and responsibility and a score of 3.52 indicates the personnel's undesirable way of being supervised and personnel's perception differences. The lowest averages are obtained from the questions regarding personnel's agreement to the decisions and mutual dependence of the personnel with scores of 2.66 and 2.61 , respectively.

Table 2. Conflict Causes Table

\begin{tabular}{|c|c|c|c|c|c|c|c|c|c|c|c|c|}
\hline \multirow{2}{*}{ EXPRESSIONS } & \multicolumn{2}{|c|}{$\begin{array}{l}\text { I completely } \\
\text { disagree }\end{array}$} & \multicolumn{2}{|c|}{ I disagree } & \multicolumn{2}{|c|}{ I am hesitant } & \multicolumn{2}{|c|}{ I agree } & \multicolumn{2}{|c|}{$\begin{array}{l}\text { I completely } \\
\text { agree }\end{array}$} & \multirow{2}{*}{ Average } & \multirow{2}{*}{ SS } \\
\hline & $\mathrm{N}$ & $\%$ & $\mathrm{~N}$ & $\%$ & $\mathrm{~N}$ & $\%$ & $\mathrm{~N}$ & $\%$ & $\mathrm{~N}$ & $\%$ & & \\
\hline Communication barriers & 13 & 8,7 & 24 & 16,0 & 26 & 17,3 & 55 & 36,7 & 32 & 21,3 & 3,46 & 1,23 \\
\hline The size of hospital & 16 & 10,7 & 43 & 28,7 & 38 & 25,3 & 45 & 30,0 & 8 & 5,3 & 2,90 & 1,10 \\
\hline $\begin{array}{c}\text { To participate in personnel } \\
\text { decisions }\end{array}$ & 29 & 19,3 & 50 & 33,3 & 25 & 16,7 & 35 & 23,3 & 11 & 7,3 & 2,66 & 1,23 \\
\hline $\begin{array}{l}\text { Have a different performance } \\
\text { criteria and reward system }\end{array}$ & 12 & 8,0 & 31 & 20,7 & 21 & 14,0 & 60 & 40,0 & 26 & 17,3 & 3,38 & 1,21 \\
\hline Staff interdependence & 26 & 17,3 & 55 & 36,7 & 29 & 19,3 & 31 & 20,7 & 9 & 6,0 & 2,61 & 1,16 \\
\hline $\begin{array}{c}\text { Authority and responsibility } \\
\text { uncertainty }\end{array}$ & 11 & 7,3 & 17 & 11,3 & 29 & 19,3 & 48 & 32,0 & 45 & 30,0 & 3,66 & 1,22 \\
\hline $\begin{array}{l}\text { Imbalance between the } \\
\text { authority and responsibility }\end{array}$ & 14 & 9,3 & 21 & 14,0 & 19 & 12,7 & 56 & 37,3 & 40 & 26,7 & 3,58 & 1,27 \\
\hline The limitation of resources & 16 & 10,7 & 22 & 14,7 & 20 & 13,3 & 65 & 43,3 & 27 & 18,0 & 3,43 & 1,24 \\
\hline $\begin{array}{l}\text { The occurrence of variations } \\
\text { due to specialization and } \\
\text { division of labor purification }\end{array}$ & 14 & 9,3 & 45 & 30,0 & 41 & 27,3 & 38 & 25,3 & 12 & 8,0 & 2,92 & 1,11 \\
\hline $\begin{array}{l}\text { The staff wants to expand the } \\
\text { areas of power }\end{array}$ & 13 & 8,7 & 38 & 25,3 & 27 & 18,0 & 53 & 35,3 & 19 & 12,7 & 3,18 & 1,19 \\
\hline $\begin{array}{l}\text { A unique management } \\
\text { approach of the managers }\end{array}$ & 13 & 8,7 & 21 & 14,0 & 25 & 16,7 & 63 & 42,0 & 28 & 18,7 & 3,48 & 1,19 \\
\hline A control method that staff do & 12 & 8,0 & 17 & 11,3 & 27 & 18,0 & 68 & 45,3 & 26 & 17,3 & 3,52 & 1,14 \\
\hline Personal differences & 18 & 12,0 & 39 & 26,0 & 25 & 16,7 & 51 & 34,0 & 17 & 11,3 & 3,06 & 1,24 \\
\hline Staff perception differences & 10 & 6,7 & 22 & 14,7 & 25 & 16,7 & 66 & 44,0 & 27 & 18,0 & 3,52 & 1,14 \\
\hline Statute differences & 16 & 10,7 & 27 & 18,0 & 25 & 16,7 & 54 & 36,0 & 28 & 18,7 & 3,34 & 1,26 \\
\hline $\begin{array}{l}\text { Staff objectives, are } \\
\text { inconsistent with the purpose } \\
\text { of hospital }\end{array}$ & 10 & 6,7 & 24 & 16,0 & 29 & 19,3 & 58 & 38,7 & 29 & 19,3 & 3,48 & 1,16 \\
\hline
\end{tabular}


As can be seen in Table3, women have a higher average than men. Women see these three statements as a cause of more conflict. Expressions; "Communication barriers", "A unique management approach of the managers", and "A control method that staffs do not want".

As shown in Table 4, as a result of an analysis of questions on age variables and measures, some differences were determined in expressions representing the conflict causes of various age groups, such as scarcity of the resources $(p=, 041)$, employee's willing to expand their force field $(p=, 027)$, employee's undesirable way of being supervised $(p=, 040)$ and inconsistency between the employee's aims and the organization's targets $(\mathrm{p}=, 019)$. As scarcity of the resources, employee's willing to expand their force field and inconsistency between the employee's aims and the foundation's targets have the highest average readings in the group of aged between 21 and 30, these expressions are seen more effective conflict causes compared with in other age groups. It was also determined that the impression of "employee's undesirable way of being supervised", had stronger potential for conflict cause for the employees' aged between 31 and 40 .

Table 3. Gender Table of Significant Differences Between the Causes of Conflict

\begin{tabular}{|c|c|c|c|c|c|}
\hline \multirow{2}{*}{ Expressions } & \multicolumn{2}{|c|}{$\mathrm{N}$} & Average & SD & P \\
\hline \multirow{2}{*}{\begin{tabular}{c} 
Communication barriers \\
\cline { 2 - 6 }
\end{tabular}} & $\mathrm{W}$ & 98 & 3.6 & 1.1 & .018 \\
\cline { 2 - 6 } A unique management approach of the \\
$\begin{array}{c}\text { managers } \\
\text { m }\end{array}$ & $\mathrm{W}$ & 98 & 3.1 & 1.0 & .025 \\
\cline { 2 - 6 } A control method that staff do not want & $\mathrm{M}$ & 52 & 3.1 & 1.3 & .006 \\
\cline { 2 - 6 } & $\mathrm{W}$ & 98 & 3.7 & 1.0 & .011 \\
\hline
\end{tabular}

Table 4. Table of Statistical Difference Regarding Conflict Causes between Age Groups

\begin{tabular}{|c|c|c|c|c|c|c|}
\hline \multicolumn{2}{|c|}{ Expressions } & $\mathrm{N}$ & Average & SS & $\mathrm{F}$ & $P$ \\
\hline \multirow{4}{*}{$\begin{array}{c}\text { Limitation of } \\
\text { Resources (ÇN8) }\end{array}$} & 21-30 Ages & 59 & 3,5763 & 1,2484 & \multirow{4}{*}{3,161} & \multirow{4}{*}{0,027} \\
\hline & 31-40 Ages & 61 & 3,5574 & 1,1765 & & \\
\hline & 41-50 Ages & 26 & 3,0000 & 1,2328 & & \\
\hline & 51 Ages and Over & 4 & 2,2500 & 1,5000 & & \\
\hline \multirow{4}{*}{$\begin{array}{l}\text { Staff want to broaden } \\
\text { the field of forces } \\
\text { (ÇN10) }\end{array}$} & 21-30 Ages & 59 & 3,4746 & 1,2085 & \multirow{4}{*}{3,161} & \multirow{4}{*}{0,027} \\
\hline & 31-40 Ages & 61 & 2,9836 & 1,1617 & & \\
\hline & 41-50 Ages & 26 & 3,1538 & 1,0841 & & \\
\hline & 51 Ages and Over & 4 & 2,0000 & 1,4142 & & \\
\hline \multirow{4}{*}{$\begin{array}{l}\text { Control method that } \\
\text { staff do not want } \\
\text { (ÇN12) }\end{array}$} & 21-30 Ages & 59 & 3,4746 & 1,1349 & \multirow{4}{*}{2,841} & \multirow{4}{*}{0,040} \\
\hline & 31-40 Ages & 61 & 3,6721 & 1,1360 & & \\
\hline & 41-50 Ages & 26 & 3,5385 & 1,0288 & & \\
\hline & 51 Ages and Over & 4 & 2,0000 & 1,4142 & & \\
\hline \multirow{4}{*}{$\begin{array}{l}\text { Staff are inconsistent } \\
\text { with the objectives of } \\
\text { corporate purpose } \\
\text { (ÇN16) }\end{array}$} & 21-30 Ages & 59 & 3,8136 & 0,9909 & \multirow{4}{*}{3,416} & \multirow{4}{*}{0,019} \\
\hline & 31-40 Ages & 61 & 3,2787 & 1,2128 & & \\
\hline & 41-50 Ages & 26 & 3,3462 & 1,2630 & & \\
\hline & 51 Ages and Over & 4 & 2,5000 & 1,2930 & & \\
\hline
\end{tabular}


Table 5. Table of Statistical Differences of Conflict Causes among Education Levels

\begin{tabular}{|c|c|c|c|c|c|c|}
\hline \multicolumn{2}{|c|}{ Expressions } & $\mathrm{N}$ & Average & SS & $\mathrm{F}$ & $\mathrm{P}$ \\
\hline \multirow{4}{*}{$\begin{array}{l}\text { Communication barriers } \\
\text { (ÇN1) }\end{array}$} & Primary School & 5 & 4,6000 & 0,5477 & \multirow{4}{*}{3,021} & \multirow{4}{*}{0,032} \\
\hline & High School or Equivalent & 54 & 3,1657 & 1,2092 & & \\
\hline & Graduate & 82 & 3,5366 & 1,2292 & & \\
\hline & Postgraduate / Doctorate & 9 & 3,8889 & 1,2693 & & \\
\hline \multirow{4}{*}{$\begin{array}{l}\text { The performance evaluation } \\
\text { criteria and differences of } \\
\text { reward system (ÇN4) }\end{array}$} & Primary School & 5 & 4,2000 & 1,3038 & \multirow{4}{*}{2,811} & \multirow{4}{*}{0,042} \\
\hline & High School or Equivalent & 54 & 3,0370 & 1,1969 & & \\
\hline & Graduate & 82 & 3,5488 & 1,1563 & & \\
\hline & Postgraduate / Doctorate & 9 & 3,4444 & 1,5092 & & \\
\hline \multirow{4}{*}{ Personal differences (ÇN13) } & Primary School & 5 & 4,2000 & 0,8366 & \multirow{4}{*}{2,861} & \multirow{4}{*}{0,039} \\
\hline & High School or Equivalent & 54 & 2,7778 & 1,1102 & & \\
\hline & Graduate & 82 & 3,1463 & 1,2777 & & \\
\hline & Postgraduate / Doctorate & 9 & 3,4444 & 1,4240 & & \\
\hline
\end{tabular}

As can be seen in Table 5, as a result of the analysis between the measures of educational background and conflict cause scores, it is ascertained that questions of conflict causes differentiated among various educational levels. Communication obstacles, performance assessment criteria and the differences of reward systems as well as personal differences are seen prominent conflict causes especially for the ones at primary education level.

\section{Discussion and Results}

In today's world, organizations prefer to hire employees with different status and professions in accordance with developing technology and increasing demand sand thereby become more complex structures. For these complex organizations, conflict is one of the issues to be managed. Conflict within organizations is one of the main chaos reasons today and the organizations should find professional ways to manage it. Healthcare organizations hire employees with different professions and an inferior employee is under the command of many superior employees in these types of organizations. As a result of this matrix organization structure in healthcare organizations, they are becoming open to conflicts. In this regard, the biggest matters of conflicts in the healthcare organizations are indicated as imbalance between authorization and responsibility and uncertainty between authorization and responsibility with scores of 3.58 and 3.66 , respectively. These two reasons can be said to point out complexity and matrix management structure in these organizations.

By nature of globalization, conflicts are inevitable facts for organizations. Therefore, conflicts should be professionally managed by the organizations. It can be claimed that the organizations need executives with strong human relations that know his organization's structure well and that utilize conflicts for the organizations interests in order to get through with minimum loss. The organizations which want to manage the change and benefit from it should succeed using conflicts through a professional executive who can determine the problems in time and use the conflict in line with the organizations interests. Healthcare organizations' need for a professional management is more apparent given their matrix and complex structures.

\section{REFERENCES}

[1] Ada ,N., (2013). Örgütlerde Çatışma Nedenleri ve Çözüm Önerileri: Bir Literatür Çalışması, 6(1), p. 65

[2] Afzalur Rahim, M., Psenicka, C., Polychroniou, P., Zhao, J. H., Yu, C. S., Anita Chan, K., ... \& Ferdausy, S. (2002). A Model Of Emotional İntelligence And Conflict Management Strategies: A Study İn Seven Countries. The International Journal Of Organizational Analysis, 10(4), p. 307.

[3] Akatay, A. (2003). Çatışma Yönetimi Ve Örgütsel Çatışma Yönetimi Teknikleri. TSA Dergisi, 7(3), p. 58.

[4] Akca C, Erigüç G (2006).Director of the Hospital Employees and Colleagues With A Research Experiences of Conflict, Hacettepe Healthcare Management Journal, Volume:2, Number:9, 127.

[5] Akkirman, A. D. (1998). Etkin çatışma yönetimi ve müdahale stratejileri, p.7

[6] Aslan, Ö, Vural, H (2004).“Faced Conflict of Nurse Managers in the environment they work and why they use Determination of Conflict Management Approach ". Nursing Forum, Volume 4, Issue 4-5, pp: 42-48.

[7] Aşçıoğlu, V. (2007). An Application in the Health Sector in Conflict Management and Business Administration. İzmir: Dokuz Eylül Üniversitesi Institute of Social Sciences Business Administration Department of Management and Organization Master's Program Thesis.

[8] Demireli, C., \& Munzur, Ç. (2012). Personelin Çatışma 
Yönetimi Algıları Ve İş Doyumu Düzeylerinin İncelenmesi: Mersin Gençlik Hizmetleri Ve Spor İl Müdürlüğü Örneği. Dumlupınar Üniversitesi Sosyal Bilimler Dergisi, 34(34), p. 296 .

[9] Doğrusöz, S. (1987), Organizational Conflict Management in Hospitals, Hacettepe

[10] University Institute of Health Sciences Health Care Management Program, Unpublished Master Thesis, Ankara.

[11] Eren, E(1991), Organization and Management, İstanbul: Beta Print.

[12] Ergün, E. (1997), Conflict Management and an Application in Organizations, Gebze Institute of Technology School of Engineering and Science, Unpublished Master's Thesis, Gebze.

[13] Gardiner, P. D., \& Simmons, J. E. L. (2003). The Relationship Between Conflict, Change and Project Management Strategy. Construction Conflict Management and Resolution, , p. 109.

[14] Kashanian, F., (1991), Conflict Management in Organizations Hospitals and University Hospitals An Investigation Against the Intergroup Conflict, İstanbul University Institute of Social Sciences, Faculty of Business Management Department of Hospital and Health Care, Unpublished Master Thesis, İstanbul.

[15] K1lınç, T. (1986). Örgütlerde Çatışma, Başa Çıkma Yöntemleri Ve Yönetimi, İstanbul Üniversitesi İşletme Fakültesi Dergisi, p.15

[16] Koçel, T., (2003), Business Management,9. printing, Beta Publishing, İstanbul.

[17] Koçel, T. (2011). İşletme Yöneticiliği, Yönetim ve Organizasyon-Organizasyonlarda Davranış-Klasik-Modern-Çağdaş Yaklaşımlar, Beta Yayımcılık, İstanbul p.645-648

[18] M. Aktaş. (2002). Dimensions of Organizational Conflict of Hospital Management, Organizational Structure and Activities A Model for Ensuring Success. Ankara.
[19] Meriç F., (2012). İșletmelerde Çatışma Yönetimi: Gaziantep Organize Sanayi Bölgesinde Bir Uygulama, Yüksek Lisans Tezi, Gaziantep, p.25-27

[20] Öztürk, A(1992), "Conflict Management in Organizations: Management Business Administration Current Threads "Çukurova University, Faculty of Economics and Administrative Sciences Publications,No:1, ss. 35- 40

[21] Rahim, M. A. (1983). A Measure of Styles of Handling Interpersonel Conflict. The Academy of Management Journal. $26(2)$.

[22] Sığrı, Ü., \& Dinçer, A. P. (2013). İşletmelerdeki İstihdam Biçimleri Ve Liderlik Tarzlarının Çatışma Yönetimi Tarzlarıyla Uyumlandırılmasına Yönelik Öneriler. Uluslararası Yönetim İktisat ve İşletme Dergisi, 9(18), p.195.

[23] Sims, R. R. (2002). Managing organizational behavior. Greenwood Publishing Group. p.246

[24] Sutton, M. K. (1976). Management of conflict. AORN journal, 23(6), p. 1093

[25] Tjosvold, D. (1991). Rights and responsibilities of dissent: Cooperative conflict. Employee Responsibilities and Rights Journal, 4(1), p.16.

[26] Türnüklü, A., Kaçmaz, T., Gürler, S., Yaka, A., Türk, U. F., Kalender, U. A., ... \& Zengin, U. F. (2009) Okul Temelli Çatışma Çözümü ve Akran Arabuluculuk Projesi. No: 106K094. Ankara: TÜBİTAK, p.5

[27] Şimşek, M. Şerif (2002), Management and Organization, Günay Ofset, Konya.

[28] Ocak, S., Gider, Ö., Top, M., Şahin, B. Ve Tarcan, M., (2004), "Muğla State Hospital Nurses' Study on the Role Ambiguity", Modern Hospital Management, Volume:8, Number:1, s: 54-62.

[29] Ohbuchi, K. I., \& Suzuki, M. (2003). Three dimensions of conflict issues and their effects on resolution strategies in organizational settings. International Journal of Conflict Management, 14(1), p. 71-72. 